\title{
Analysis Quality Control of Garnish Back Door License in Injection Molding Process Using DMAIC Method and VSM Method at PT. Suzuki Indomobil Motor
}

\author{
Erry Rimawan*, Muhammad Kholil, Sarah Fachira \\ College of Engineering, Mercubuana University, West Jakarta, 11650, Indonesia
}

Received July 31, 2019; Revised December 20, 2019; Accepted December 23, 2019

Copyright@2019 by authors, all rights reserved. Authors agree that this article remains permanently open access under the terms of the Creative Commons Attribution License 4.0 International License

\begin{abstract}
PT. Suzuki Indomobil Motor is a leading automotive company in Indonesia that produces products in the form of cars and motorcycles, a quality phenomenon that occurred during January 2019 at PT. Suzuki Indomobil Motor there is a high silver streak defect in the injection molding section with 169 back door license garnish that are attached to the machine A02. With this phenomenon, this study aims to determine the injection molding process using value stream mapping and improve the quality of the garnish back door license products using the DMAIC. The results obtained showed that there was a changeover time dies on the Machine A02 that was as high as 57.15 minutes with uptime values and the highest type of defect was obtained using the pareto diagram namely silver streak defect with a percentage of $43 \%$. So from the recommendations obtained by using the value stream mapping to minimize the changeover time dies of the Machine A02, namely by heating the dies first before dies go up to the injection machine, and recommendations obtained from the DMAIC method that is by controlling the stock of material and temperature in the hopper dryer.
\end{abstract}

Keywords Value Stream Mapping, DMAIC (Define, Measure, Improve, Control), Injection Molding

\section{Introduction}

\subsection{Background}

The development of the automotive industry, especially four-wheeled vehicles from year to year, shows an increasing development. This is supported by the increasing purchasing power of the people on marketed products. Besides that, it is also supported by the high mobility needs of the community with the demands of a lifestyle that requires each individual to have a private vehicle as a means of supporting the transfer from one place to another in a faster, safer and more convenient way. The choice is of course four-wheeled vehicles or we usually call cars.

PT. Suzuki Indomobil Motor as a provider of international scale vehicles with global standards is certainly responsive to the needs of this community. With the aim of increasing the area of the broad four-wheeled vehicle market, we are familiar with PT. Suzuki Indomobil Motor has a car assembly \& marketing company in almost all countries in the world.

By considering customer satisfaction and ensuring safety to user / vehicle users, improving quality to the level of suppliers is considered very important. One method of improving quality is the Six Sigma method. The Six Sigma method is a philosophy that requires products when produced only to have a ratio of the number of defects of 3.4: 1000000 which means that a production is said to reach Six Sigma if the percentage of defects of one million products is only 3.4. In other words the level of OK product ratio to be able to meet the Six Sigma level is 99.99966.

From the results of observations at PT. Suzuki Indomobil Motor obtained production data regarding the number of defective products and ok products of plastic injection production, along with data on third car parts production (YHA) garnish back door license: 
Injection Molding Process Using DMAIC Method and VSM Method at PT. Suzuki Indomobil Motor

Table 1. Defect Garnish Back Door License in April 2018-January 2019

\begin{tabular}{|c|c|c|c|c|c|c|c|c|}
\hline Month & Short Shoot & Weld Line & Silver Streak & Dekok & Flowmark & Other & Total NG & Total OK \\
\hline April & 17 & 0 & 49 & 0 & 20 & 0 & 86 & 2154 \\
\hline May & 44 & 0 & 60 & 0 & 10 & 5 & 119 & 5486 \\
\hline June & 46 & 0 & 115 & 6 & 19 & 0 & 186 & 5128 \\
\hline July & 49 & 1 & 86 & 0 & 0 & 3 & 139 & 6758 \\
\hline August & 21 & 0 & 6 & 0 & 6 & 0 & 33 & 3854 \\
\hline September & 23 & 0 & 0 & 0 & 6 & 28 & 57 & 3699 \\
\hline October & 16 & 0 & 0 & 0 & 4 & 16 & 36 & 2571 \\
\hline November & 0 & 0 & 0 & 0 & 0 & 9 & 9 & 1251 \\
\hline December & 0 & 0 & 0 & 0 & 0 & 0 & 0 & 1446 \\
\hline January & 69 & 0 & 169 & 0 & 56 & 99 & 393 & 3416 \\
\hline Total & 285 & 1 & 485 & 6 & 121 & 160 & 1058 & 35763 \\
\hline
\end{tabular}

Source: PT. Suzuki Indomobil Motor

From the total defect back door license data for April 2018-January 2019, it can be seen that in January 2019 it was the largest NG product during the period April 2018January 2019. Therefore, corrective actions were needed so that the types of defects that occurred could be minimized.

To perform these corrective actions, the DMAIC method will be used (Define, Measure, Analyze, Improve, Control). DMAIC is a cycle of improvement based on data (performance data), is complementary and is the basis for companies or organizations to make continuous improvement (continuous improvement), which is used to improve, optimize and stabilize the production process for a change (Hassan , 2013).

\subsection{Formulation of the Problem}

1. How does the Injection Molding process use Value Stream Mapping (VSM)?

2. How to improve the quality of Garnish Back Door License products with the DMAIC method?

\subsection{Research Purposes}

1. To find out the Injection Molding process by using Value Stream Mapping (VSM)

2. To improve the quality of the Garnish Back Door License product with the DMAIC method.

\subsection{Scope of Problem}

1. Observation of the quality control process carried out in the process of injection molding the Garnish Back Door License part at PT. Suzuki Indomobil Motor.

2. The data used in this study are defect data in the January 2019 Garnish Back Door License part owned by PT. Suzuki Indomobil Motor.

3. Analysis of the problem is only done on the A02 engine.

4. The method approach and discussion carried out in this study only cover the DMAIC and VSM methodologies.
5. There are no change factors that influence when taking data.

6. Each production process carried out on the A02 engine is a part of the car component.

7. The production process of the Garnish Back Door License in the A02machine from the process of preparing raw materials to the packing process at the YHA warehouse (third)

\section{Literature Review}

\subsection{Six Sigma}

According to (Yadav, 2014), Six Sigma is a way to implement better quality standards. This is a philosophy and methodology that improves quality by analyzing data with statistics to find the root causes of quality problems and apply controls.

According to (Salomon, 2015), the aim of the six quality improvement program sigma is to improve the management system of a company or other institutions related to customers. Then use it to repair production processes that are focused on efforts to reduce process variants while reducing defects, so as to reach 3.4 DPMO.

\subsection{Quality}

According to (Sumayang, 2003), Control Charts are the primary means for implementing statistical quality control methods. Control chart is a collection of data written in graphical form and used to make an assessment of the status of quality control in a production process.

\subsection{Quality Control}

According to (Purnomo, 2003) states, the quality control is a process control activity to measure product quality characteristics, compare them with specifications or requirements, and take appropriate sanitary measures if 
there is a difference between the actual appearance and the standard. The purpose of quality control is to control the quality of products or services that can satisfy consumers.

\subsection{Value Stream Mapping (VSM)}

According to (Jeong, 2016), Value Stream Mapping (VSM) is a way standards for documenting the process and flow of information or material as is, and applies a systematic way to analize this process to identify various wastes and target specific areas to improvement.

\section{Method}

In this study to meet or achieve the research objectives in order to complete the final assignment, the types of data and information needed, among others:

\subsection{Primary Data}

According to (Sugiyono, 2012), primary data is a source of data that directly provides data to data collectors. Primary data collection in this study includes:

a. Data from the FMEA questionnaire conducted by the quality team of PT. Suzuki Indomobil Motor.

b. Interview regarding the general description of the production process to the head of the production of Injection Molding PT. Suzuki Indomobil Motor. c. Interview regarding raw material used in the Injection Molding process to the production head of raw material PT. Suzuki Indomobil Motor.

d. Interview about the description of the type of silver streak defect, weld line, dekok, flowmark, short shoot, and other products on the Garnish Back Door License.

e. Interview regarding the flow of material from the supplier to the customer's hands and to the head of Injection Molding production and the PPIC team.

\subsection{Secondary Date}

According to (Sugiyono, 2012), Secondary data is data obtained by reading, studying and understanding through other media sources of literature, books, and company documents. Secondary data collection in this study includes:

a. Data on the number of products are ok and NG products are YHA car components (third) Injection Molding production process for April 2018 - January 2019

\section{Research Result and Discussion}

Based on observations on the production process of Injection Molding, obtained data on the number of defect parts of the GaBack Door License in January 2019 are as follows:

Table 2. Total Data Garnish Back Door License Januari 2019

\begin{tabular}{|c|c|c|c|c|c|c|c|}
\hline Date & Total OK & Short Shoot & Weld Line & Silver Streak & Dekok & Flowmark & Other \\
\hline $1 / 2 / 2019$ & 159 & 0 & 0 & 0 & 0 & 0 & 0 \\
\hline $1 / 3 / 2019$ & 120 & 0 & 0 & 0 & 0 & 0 & 0 \\
\hline $1 / 5 / 2019$ & 150 & 0 & 0 & 15 & 0 & 0 & 0 \\
\hline $1 / 7 / 2019$ & 280 & 0 & 0 & 0 & 0 & 0 & 0 \\
\hline $1 / 8 / 2019$ & 120 & 0 & 0 & 0 & 0 & 0 & 0 \\
\hline $1 / 9 / 2019$ & 235 & 0 & 0 & 0 & 0 & 0 & 0 \\
\hline $1 / 12 / 2019$ & 183 & 0 & 0 & 0 & 0 & 0 & 0 \\
\hline $1 / 15 / 2019$ & 120 & 0 & 0 & 0 & 0 & 0 & 0 \\
\hline $1 / 16 / 2019$ & 180 & 0 & 0 & 0 & 0 & 0 & 0 \\
\hline $1 / 17 / 2019$ & 174 & 0 & 0 & 0 & 0 & 0 & 0 \\
\hline $1 / 21 / 2019$ & 232 & 10 & 0 & 18 & 0 & 0 & 15 \\
\hline $1 / 22 / 2019$ & 113 & 2 & 0 & 10 & 0 & 6 & 30 \\
\hline $1 / 23 / 2019$ & 150 & 6 & 0 & 7 & 0 & 13 & 12 \\
\hline $1 / 24 / 2019$ & 143 & 2 & 0 & 7 & 0 & 2 & 0 \\
\hline $1 / 25 / 2019$ & 352 & 15 & 0 & 46 & 0 & 10 & 0 \\
\hline $1 / 28 / 2019$ & 140 & 6 & 0 & 26 & 0 & 7 & 0 \\
\hline $1 / 29 / 2019$ & 179 & 5 & 0 & 11 & 0 & 0 & 29 \\
\hline $1 / 30 / 2019$ & 226 & 15 & 0 & 17 & 0 & 5 & 13 \\
\hline $1 / 31 / 2019$ & 160 & 8 & 0 & 12 & 0 & 13 & 0 \\
\hline
\end{tabular}




\subsection{Define Phase}

\section{- $\quad$ SIPOC Diagram}

According to (Syukron, 2013), each of the six sigma projects that have been selected key processes, sequence of processes, and their interactions must be defined by customers involved in each of the processes. These customers can become internal and external customers. Before defining key processes and customers in the Six Sigma project, we need to know the SIPOC process (Supplier, Input, Process, Output, Customer). The SIPOC diagram presents a brief view of the work flow as follows: SIPOC (Supplier, Input, Process, Output, Customer)

Supplier : PT. Toyota Tsusho Indonesia

Input : Plastic seeds (ABS Toray 440Y)

Process: Mixing material in tank material, drying material in hopper dryer, injection molding process, inspection part, packaging, delivery, storage.

Output : Garnish, Back Door License

Customer : Painting Department

\section{- $\quad$ CTQ (Critical To Quality)}

According to (Pande, 2002), Critical To Quality are the requirements desired by the customer. Based on the results of interviews with Quality Control at PT. Suzuki Indomobil Motor. The results also show that CTQ (Physical To Quality) consists of physical conditions on the part produced. The physical condition consists of the following:
Table 3. CTQ Part Garnish Back Door License

\begin{tabular}{|c|c|}
\hline CTQ & Information \\
\hline Not Silver Streak & There are no silvery patches \\
\hline No Short Shoot & $\begin{array}{c}\text { Perfect part (whole) } \\
\text { No Flow Mark }\end{array}$ \\
\hline No Weld Line & There is no pattern of material flow on the pattern line meeting material flow \\
\hline No Dekok & The surface of the part is not concave \\
\hline Others & $\begin{array}{c}\text { There are no other defects other than the } \\
\text { above categories, for example oily, different } \\
\text { colors, collisions, etc. }\end{array}$ \\
\hline
\end{tabular}

\section{- $\quad$ Current State Mapping}

Data from each process is collected manually by carrying out observations and actual time calculations that occur on the production floor. In making the current state map there are calculations as follows:

\section{- $\quad$ Available Time (AT)}

The total available work time per day is calculated by reducing 9 hours of work with a 40 minute break, then:

Available work time $=$ working hours per day - rest periods

$=540$ minutes -40 minutes

$=500$ minutes

\section{- $\quad$ Change overtime (C / O)}

Obtained based on the length of time the operator makes changes to dies (prints) on the injection molding machine.

Table 3. Current State Map

\begin{tabular}{|c|c|c|c|c|c|c|c|c|c|c|c|}
\hline \multirow{2}{*}{ No. } & \multirow{2}{*}{ Process } & \multirow{2}{*}{$\begin{array}{c}\text { Processing Time } \\
\text { (hour.minute.second) }\end{array}$} & \multirow{2}{*}{$\begin{array}{c}\mathrm{C} / \mathrm{O} \\
\text { (minute) }\end{array}$} & \multirow{2}{*}{$\begin{array}{c}\text { Available } \\
\text { Time } \\
\text { (minute) }\end{array}$} & \multirow{2}{*}{ Uptime } & \multicolumn{5}{|c|}{ Aliran } & \multirow{2}{*}{ VA/NVA } \\
\hline & & & & & & $\mathrm{O}$ & $\mathrm{T}$ & I & $\mathrm{S}$ & D & \\
\hline 1. & $\begin{array}{c}\text { Raw Material } \\
\text { Preparation }\end{array}$ & 02.26 .25 & 0 & 500 & $100 \%$ & & & & & & VA \\
\hline 2. & Injection Molding & 04.18 & 57.15 & 500 & $88.57 \%$ & & & & & & NVA \\
\hline 3. & Packing & 08.18 & 0 & 500 & $100 \%$ & & & & & & VA \\
\hline
\end{tabular}




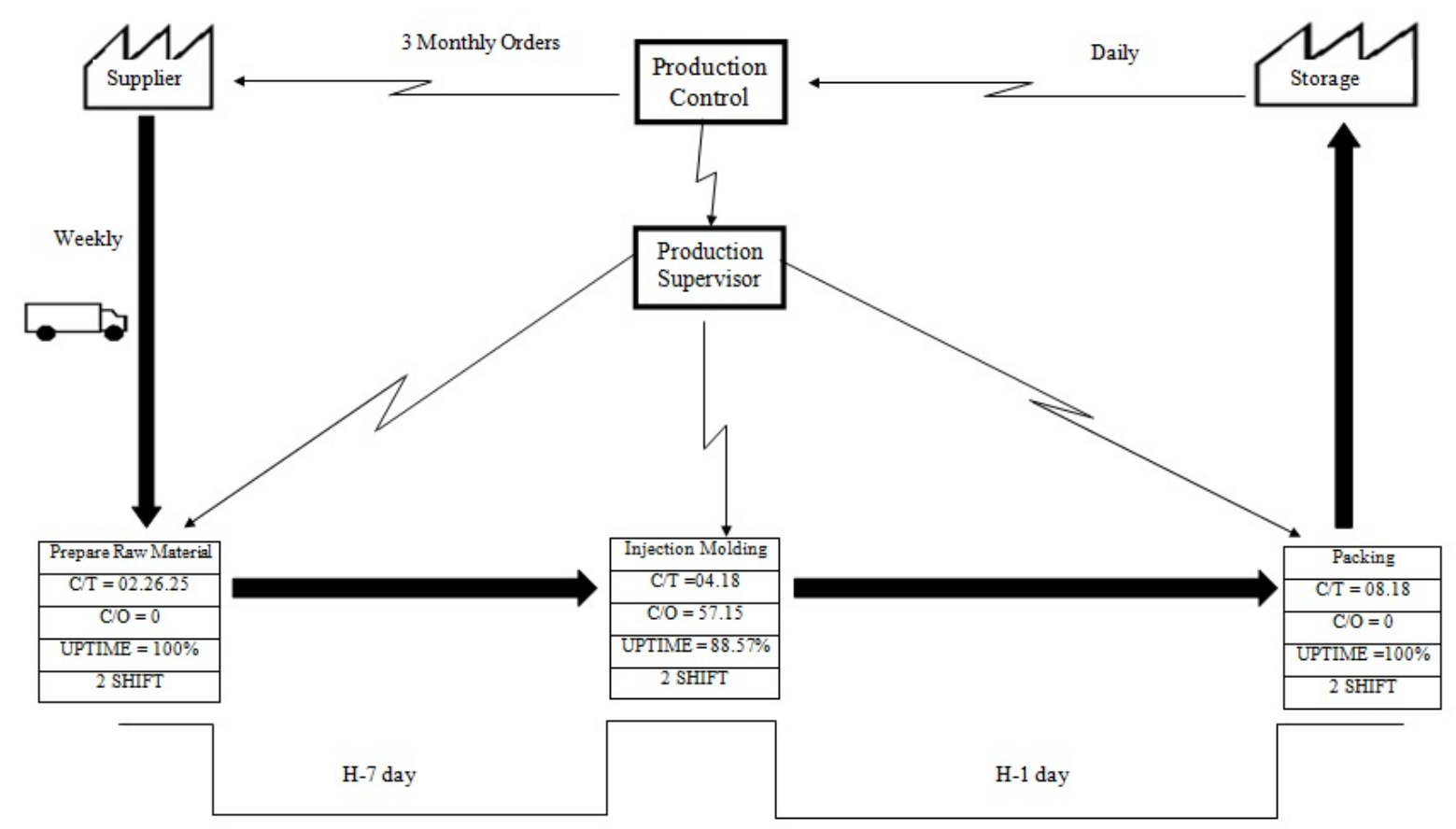

Figure 1. Current State Map

\section{- Uptime}

Calculated by reducing available time minus change over time divided by available time. Uptime for changing dies is:

Uptime $=(($ available time-changeover time $)) /$ (available time) $\times 100 \%$

Uptime $=((500-0)) / 500 \times 100 \%$

Uptime $=100 \%$

From the above calculation, the data table is obtained to make the current state map in the injection molding process on the A02 machine, as Table 3.

It can be seen from the picture above shows that there is a high changeover time, which is equal to 57.15 minutes with an uptime value of $88.57 \%$, therefore a corrective action is needed so that the changeover time is reduced to increase the productivity value in the injection molding process in Machine A02.

\subsection{Measure Phase}

\section{- $\quad$ Pareto Diagram}

In the production process of Garnish Back Door License, there are types of defects such as defect silver streak, short shoot, flowmark, weld line, dekok, and other, to reduce the scope, the selection of defects is the biggest among existing defects, because it is in accordance with the philosophy In Pareto $80 \%$ of problems can be solved by overcoming the $20 \%$ of the biggest problems. The following are the steps to make a calculation of the pareto diagram of the type of product defect in the Garnish Back Door License in January 2019:

Table 4. Defect Garnish Back Door License Januari 2019

\begin{tabular}{|c|c|c|c|}
\hline $\begin{array}{c}\text { Type of } \\
\text { Defect }\end{array}$ & $\begin{array}{c}\text { Total Defect } \\
\text { (pcs) }\end{array}$ & $\begin{array}{c}\text { Percentag } \\
\text { e }\end{array}$ & $\begin{array}{c}\text { Cumulative } \\
\text { Percentage }\end{array}$ \\
\hline Silver Streak & 169 & $43 \%$ & $43 \%$ \\
\hline Other & 99 & $25 \%$ & $68 \%$ \\
\hline Short Shoot & 69 & $18 \%$ & $86 \%$ \\
\hline Flowmark & 56 & $14 \%$ & $100 \%$ \\
\hline Weld Line & 0 & $0 \%$ & $100 \%$ \\
\hline Dekok & 0 & $0 \%$ & $100 \%$ \\
\hline Total & 393 & $100 \%$ & \\
\hline
\end{tabular}

- Examples of calculations in the table are as follows: Percentage $=\frac{\text { number of defects per type of defect }}{\text { total number of defects }} \times 100$ example :

percentage of silver streak $=\frac{169}{393} \times 100=43 \%$

- $\quad$ Cumulative percentage $=$ percentage of the period + previous cumulative percentage

example: cumulative percentage of silver streak $=43 \%+$ $0 \%=43 \%$

From the data table above it can be concluded that the main cause of defects is silver streak with a percentage of defects of $43 \%$ and therefore special attention is needed so that defects that arise can be reduced. 


\section{Diagram Pareto}

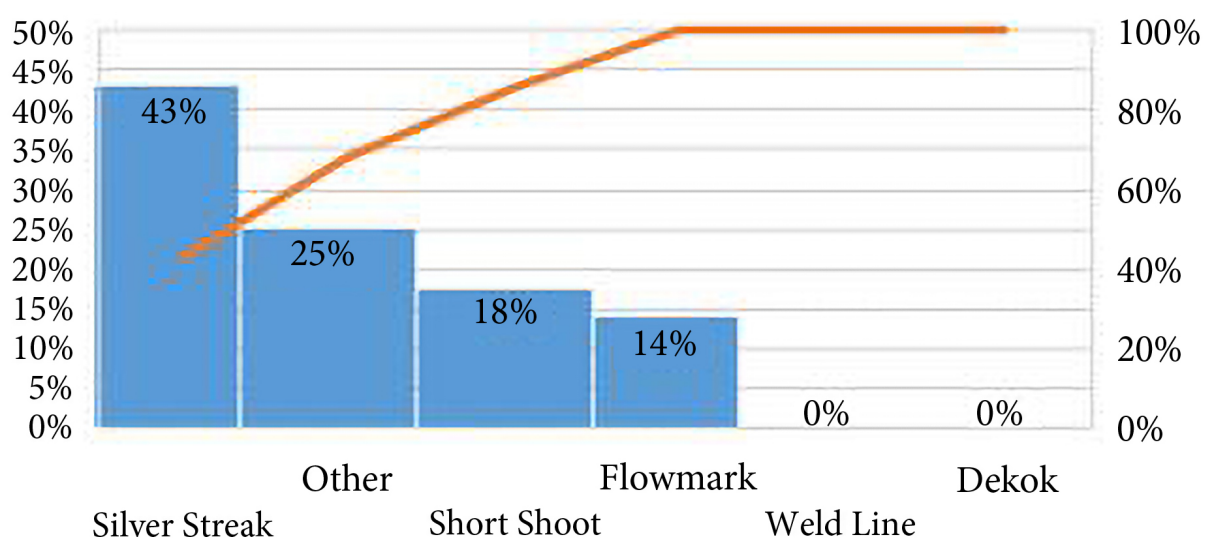

Figure 2. Pareto Diagram

\section{- Control Chart}

Because the data obtained from PT. Suzuki Indomobil Motor is in the form of attribute data, to verify the data using the control chart and made based on the data contained in the table, namely data on the number of defects and the number of panel meter production. Data processing is done on control chart by using the product defect control limit. The standard control chart $\mathrm{p}$ is as follows: (Gasperz, 1998)

The steps in calculating a control map p:

1. Calculate for each subgroup the value of the proportion of unit defects

2. Calculate the average of $p$

3. Calculate the control limit for control chart

$$
\begin{gathered}
\dot{p}=\frac{\text { total defect }}{\text { total production }}=\frac{169}{3809}=0.04 \\
\mathrm{UCL}=\mathrm{p}+3 \sqrt{\frac{\mathrm{p}(1-\mathrm{p})}{\mathrm{n}}}
\end{gathered}
$$

$$
\begin{gathered}
\mathrm{UCL}=0.04+3 \sqrt{\frac{0.04(1-0.04)}{159}} \\
\mathrm{UCL}=0.09 \\
\mathrm{LCL}=\mathrm{p}-3 \sqrt{\frac{\mathrm{p}(1-\mathrm{p})}{\mathrm{n}}} \\
\mathrm{LCL}=0.04-3 \sqrt{\frac{0.04(1-0.04)}{159}} \\
\mathrm{LCL}=-0.006
\end{gathered}
$$

2. Plotting the value of UCL, CL, LCL into table form

From the calculation of the data above, to find out whether every day the panel meter production process in January 2019 is still within the control limit, a table of control charts is made by plotting the CL, UCL, LCL values. 
Table 5. Control Chart

\begin{tabular}{|c|c|c|c|c|c|c|}
\hline Periode & Total Production & Total Defect & Proporsition Defect & CL & LCL & UCL \\
\hline $1 / 2 / 2019$ & 159 & 0 & 0.00 & 0.04 & $(0.006)$ & 0.09 \\
\hline $1 / 3 / 2019$ & 120 & 0 & 0.00 & 0.04 & $(0.013)$ & 0.10 \\
\hline $1 / 5 / 2019$ & 165 & 15 & 0.09 & 0.04 & $(0.005)$ & 0.09 \\
\hline $1 / 7 / 2019$ & 280 & 0 & 0.00 & 0.04 & 0.007 & 0.08 \\
\hline $1 / 8 / 2019$ & 120 & 0 & 0.00 & 0.04 & $(0.013)$ & 0.10 \\
\hline $1 / 9 / 2019$ & 235 & 0 & 0.00 & 0.04 & 0.003 & 0.09 \\
\hline $1 / 12 / 2019$ & 183 & 0 & 0.00 & 0.04 & $(0.002)$ & 0.09 \\
\hline $1 / 15 / 2019$ & 120 & 0 & 0.00 & 0.04 & $(0.013)$ & 0.10 \\
\hline $1 / 16 / 2019$ & 180 & 0 & 0.00 & 0.04 & $(0.003)$ & 0.09 \\
\hline $1 / 17 / 2019$ & 174 & 0 & 0.00 & 0.04 & $(0.004)$ & 0.09 \\
\hline $1 / 21 / 2019$ & 275 & 18 & 0.07 & 0.04 & 0.006 & 0.08 \\
\hline $1 / 22 / 2019$ & 161 & 10 & 0.06 & 0.04 & $(0.005)$ & 0.09 \\
\hline $1 / 23 / 2019$ & 188 & 7 & 0.04 & 0.04 & $(0.002)$ & 0.09 \\
\hline $1 / 24 / 2019$ & 154 & 7 & 0.05 & 0.04 & $(0.007)$ & 0.10 \\
\hline $1 / 25 / 2019$ & 423 & 46 & 0.11 & 0.04 & 0.014 & 0.08 \\
\hline $1 / 28 / 2019$ & 179 & 26 & 0.15 & 0.04 & $(0.003)$ & 0.09 \\
\hline $1 / 29 / 2019$ & 224 & 11 & 0.05 & 0.04 & 0.002 & 0.09 \\
\hline $1 / 30 / 2019$ & 276 & 17 & 0.06 & 0.04 & $(0.001)$ & 0.09 \\
\hline $1 / 31 / 2019$ & 193 & 169 & 0.73 & & 0.08 \\
\hline Total & 3809 & & & & \\
\hline
\end{tabular}

\section{Peta Kendali P}

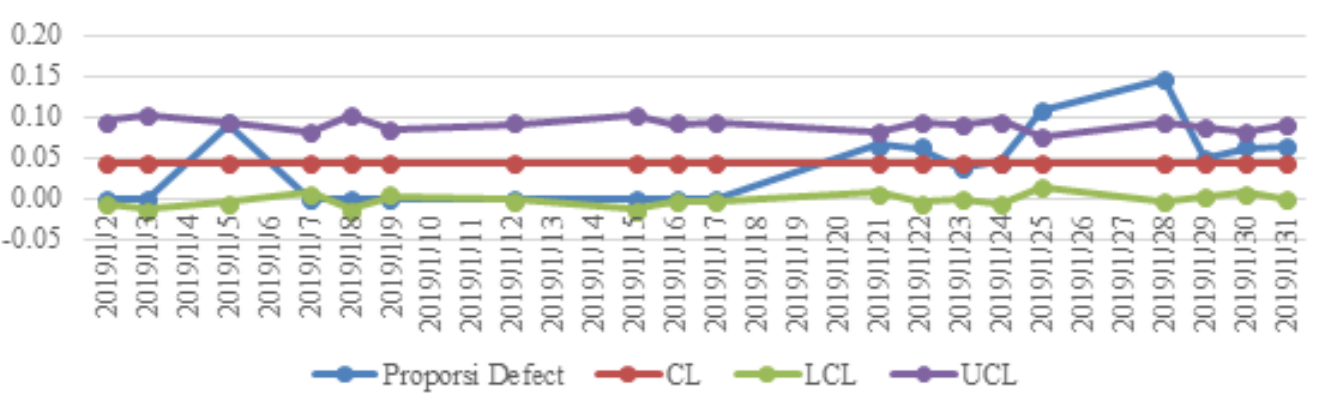

Figure 3. Control Chart

From the graph above, there is uncontrolled data (out of UCL), namely on 25 \& 28 January 2019, therefore to improve the above graph it is enough to eliminate data that comes out of the control boundary, and for that the control limit must be corrected.

\section{- Calculation of DPO (Defect Per Opportunities) and DPMO (Defect Per Million Opportunities)}

Calculating DPO (Defect Per Opportunities), which is a measure of failure that shows the number of defects per opportunity.

$$
\text { DPO }=\frac{\text { DPU (Defect Per Unit) }}{\text { OutputxCTQ Potensial }}
$$

$$
\mathrm{DPO}=\frac{15}{165 \times 6}=0.0152
$$

Calculating DPMO (Defect Per Million Opportunities), which is a measure of failure that shows most millionth chance defects.

$$
\text { DPMO = DPO X 1.000.000 }
$$

\section{- SQL (Sigma Quality Level)}

SQL (Sigma Quality Level) is an indicator that describes the level of performance process, and to look for sigma values can be directly seen from the six sigma conversion table.

$$
\begin{gathered}
\mathrm{DPMO}=0.0152 \times 1000000 \\
\mathrm{DPMO}=15152
\end{gathered}
$$


Analysis Quality Control of Garnish Back Door License in

Injection Molding Process Using DMAIC Method and VSM Method at PT. Suzuki Indomobil Motor

Table 6. DPMO and SQL Garnish Back Door License January 2019

\begin{tabular}{|c|c|c|c|c|c|c|}
\hline Date & Total Production (unit) & Total Defect (unit) & CTQ & DPO & DPMO & SQL \\
\hline $2 / 01 / 2019$ & 159 & 0 & 6 & 0 & 0 & 6 \\
\hline 3/01/2019 & 120 & 0 & 6 & 0 & 0 & 6 \\
\hline $5 / 01 / 2019$ & 165 & 15 & 6 & 0.0152 & 15152 & 3.7 \\
\hline $7 / 01 / 2019$ & 280 & 0 & 6 & 0 & 0 & 6 \\
\hline 8/01/2019 & 120 & 0 & 6 & 0 & 0 & 6 \\
\hline 9/01/2019 & 235 & 0 & 6 & 0 & 0 & 6 \\
\hline $12 / 01 / 2019$ & 183 & 0 & 6 & 0 & 0 & 6 \\
\hline 15/01/2019 & 120 & 0 & 6 & 0 & 0 & 6 \\
\hline 16/01/2019 & 180 & 0 & 6 & 0 & 0 & 6 \\
\hline $17 / 01 / 2019$ & 174 & 0 & 6 & 0 & 0 & 6 \\
\hline 21/01/2019 & 275 & 43 & 6 & 0.0261 & 26061 & 3.5 \\
\hline 22/01/2019 & 161 & 48 & 6 & 0.0497 & 49689 & 3.2 \\
\hline 23/01/2019 & 188 & 38 & 6 & 0.0337 & 33688 & 3.4 \\
\hline 24/01/2019 & 154 & 11 & 6 & 0.0119 & 11905 & 3.8 \\
\hline 25/01/2019 & 423 & 71 & 6 & 0.0280 & 27975 & 3.5 \\
\hline 28/01/2019 & 179 & 39 & 6 & 0.0363 & 36313 & 3.3 \\
\hline 29/01/2019 & 224 & 45 & 6 & 0.0335 & 33482 & 3.4 \\
\hline $30 / 01 / 2019$ & 276 & 50 & 6 & 0.0302 & 30193 & 3.4 \\
\hline 31/01/2019 & 193 & 33 & 6 & 0.0285 & 28497 & 3.5 \\
\hline Total & 3809 & 393 & & & & 3.4 \\
\hline
\end{tabular}

From the table above, it can be seen that the average DPMO value is 15419 and the SQL 3.4 value is sigma. This shows that the relative baseline of the company's performance is not good and that quality improvements need to be carried out continuously to reach 6 sigma.

\section{- $\quad$ Yield Process}

Yield is the magnitude of the probability of a product that is not defective in the inspected part. The calculation starts from looking for the DPU (Defect Per Unit) value. Calculation of DPU in January 2019 is as follows:

$$
\text { DPU }=\frac{\text { Defect }}{\text { Jumlah Produksi }}
$$

$$
\mathrm{DPU}=\frac{15}{165}=0.09
$$

Then look for the yield value in January 2019 with the following calculation formula:

$$
\text { Yield }=\mathrm{e}^{-\mathrm{dpu}}
$$

$$
\begin{gathered}
\text { Yield }=2.7183^{-0.09}=0.914 \\
\text { Yield \% }=\text { Yield x100 } \\
\text { Yield \% }=0.914 \text { x } 100=>91 \%
\end{gathered}
$$

More information on yield values during January 2019 can be seen in the following table 
Table 7. Results of yield calculation

\begin{tabular}{|c|c|c|c|c|c|}
\hline Date & Total Production (unit) & Total Defect (unit) & DPU & Yield & Yield\% \\
\hline $2 / 01 / 2019$ & 159 & 0 & 0 & 1 & 100 \\
\hline 3/01/2019 & 120 & 0 & 0 & 1 & 100 \\
\hline $5 / 01 / 2019$ & 150 & 15 & 0.09 & 0.914 & 91 \\
\hline $7 / 01 / 2019$ & 280 & 0 & 0 & 1 & 100 \\
\hline 8/01/2019 & 120 & 0 & 0 & 1 & 100 \\
\hline $9 / 01 / 2019$ & 235 & 0 & 0 & 1 & 100 \\
\hline $12 / 01 / 2019$ & 183 & 0 & 0 & 1 & 100 \\
\hline $15 / 01 / 2019$ & 120 & 0 & 0 & 1 & 100 \\
\hline $16 / 01 / 2019$ & 180 & 0 & 0 & 1 & 100 \\
\hline $17 / 01 / 2019$ & 174 & 0 & 0 & 1 & 100 \\
\hline 21/01/2019 & 232 & 43 & 0.16 & 0.852 & 85 \\
\hline 22/01/2019 & 113 & 48 & 0.30 & 0.741 & 74 \\
\hline 23/01/2019 & 150 & 38 & 0.20 & 0.819 & 82 \\
\hline $24 / 01 / 2019$ & 143 & 11 & 0.07 & 0.932 & 93 \\
\hline 25/01/2019 & 352 & 71 & 0.17 & 0.844 & 84 \\
\hline 28/01/2019 & 140 & 39 & 0.22 & 0.803 & 80 \\
\hline 29/01/2019 & 179 & 45 & 0.20 & 0.819 & 82 \\
\hline $30 / 01 / 2019$ & 226 & 50 & 0.18 & 0.835 & 84 \\
\hline $31 / 01 / 2019$ & 160 & 33 & 0.17 & 0.844 & 84 \\
\hline Total & 3416 & 393 & & & \\
\hline Rata-Rata & & & 0.09 & 0.916 & 92 \\
\hline
\end{tabular}

From the table above, it can be seen that the probability percentage of products that are not defective in the inspected part is $92 \%$.

\subsection{Analyze Phase}

In the analyze stage, the analysis is done by analyzing the problems that occur in aspects of quality control, so that later it is expected to reduce defective products that occur in the production process. This stage is done by analyzing the sources that make a silver streak defect in the Garnish Back Door License part at PT. Suzuki Indomobil Motor, and identification is seen from human factors, material methods, machines, and environment using fishbone diagram as follows:

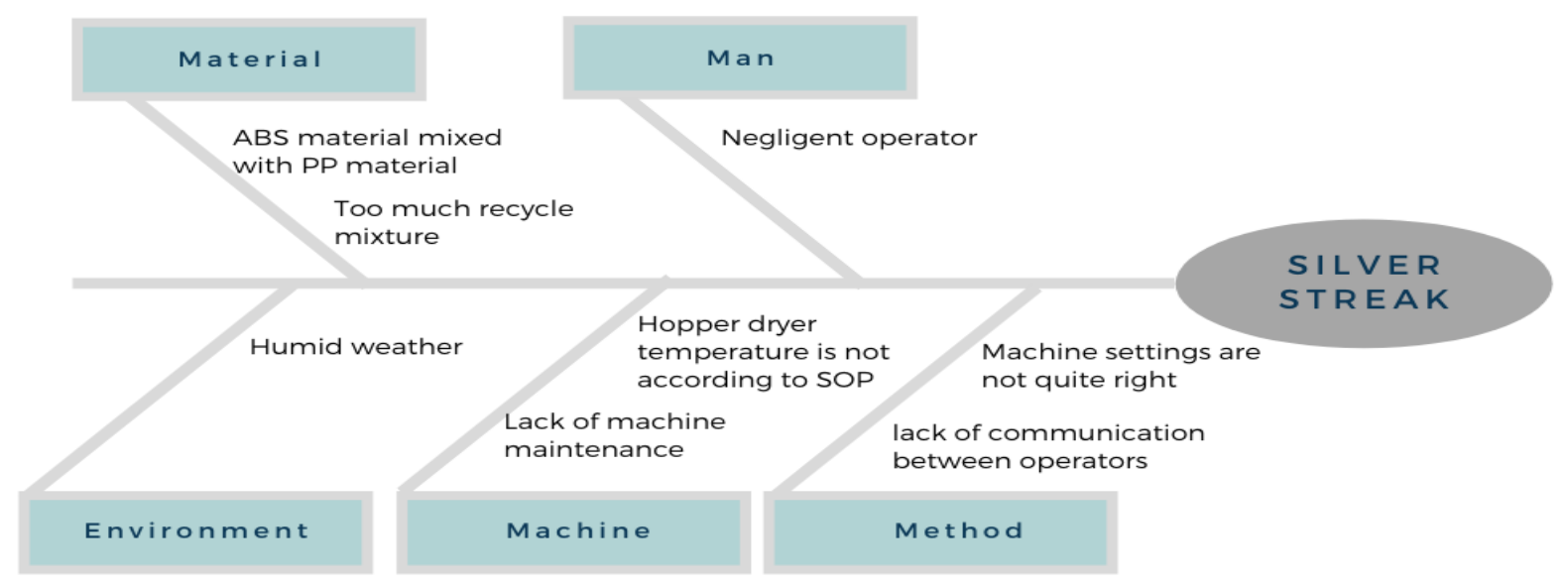

Figure 4. Fish Bone Diagrams Defect Garnish Back Door License 


\subsection{Improve Phase}

The fourth stage of the DMAIC method is improving. At this stage the process time is repaired on the injection molding machine on the A02 engine in the form of a future state map. In making the future state map there are calculations as follows:

1. Available Time (AT)

The total available work time per day is calculated by reducing 9 hours of work with a 40 minute break, then :

Available work time $=$ working hours per day - rest periods

$=540$ minutes -40 minutes

$=500$ minutes

2. Change overtime $(\mathrm{C} / \mathrm{O})$

Obtained based on the length of time the operator makes changes to dies (prints) on the injection molding machine.

\section{Uptime}

Calculated by reducing available time minus change over time divided by available time. Uptime for changing dies is:

$$
\begin{gathered}
\text { Uptime }=\frac{(\text { available time }- \text { changeover time })}{\text { avaiable time }} \times 100 \% \\
\text { Uptime }=\frac{(500-45.14)}{500} \times 100 \%
\end{gathered}
$$

Uptime $=90.97 \%$

From the above calculation, a table of data is obtained to make the future state map in the injection molding process on the A02 machine, as follows;

Table 8. Future State Map

\begin{tabular}{|c|c|c|c|c|c|}
\hline No & Process & $\begin{array}{c}\text { Processing Time } \\
\text { (hour.minute.second) }\end{array}$ & $\begin{array}{c}\text { C/O } \\
\text { (minute) }\end{array}$ & $\begin{array}{c}\text { Available Time } \\
\text { (minute) }\end{array}$ & Uptime \\
\hline 1 & $\begin{array}{c}\text { Preparation of raw } \\
\text { material }\end{array}$ & 02.26 .25 & 0 & 500 & $100 \%$ \\
\hline 2 & Injection Molding & 04.18 & 45.14 & 500 & $90.97 \%$ \\
\hline 3 & Packing & 08.18 & 0 & 500 & $100 \%$ \\
\hline
\end{tabular}

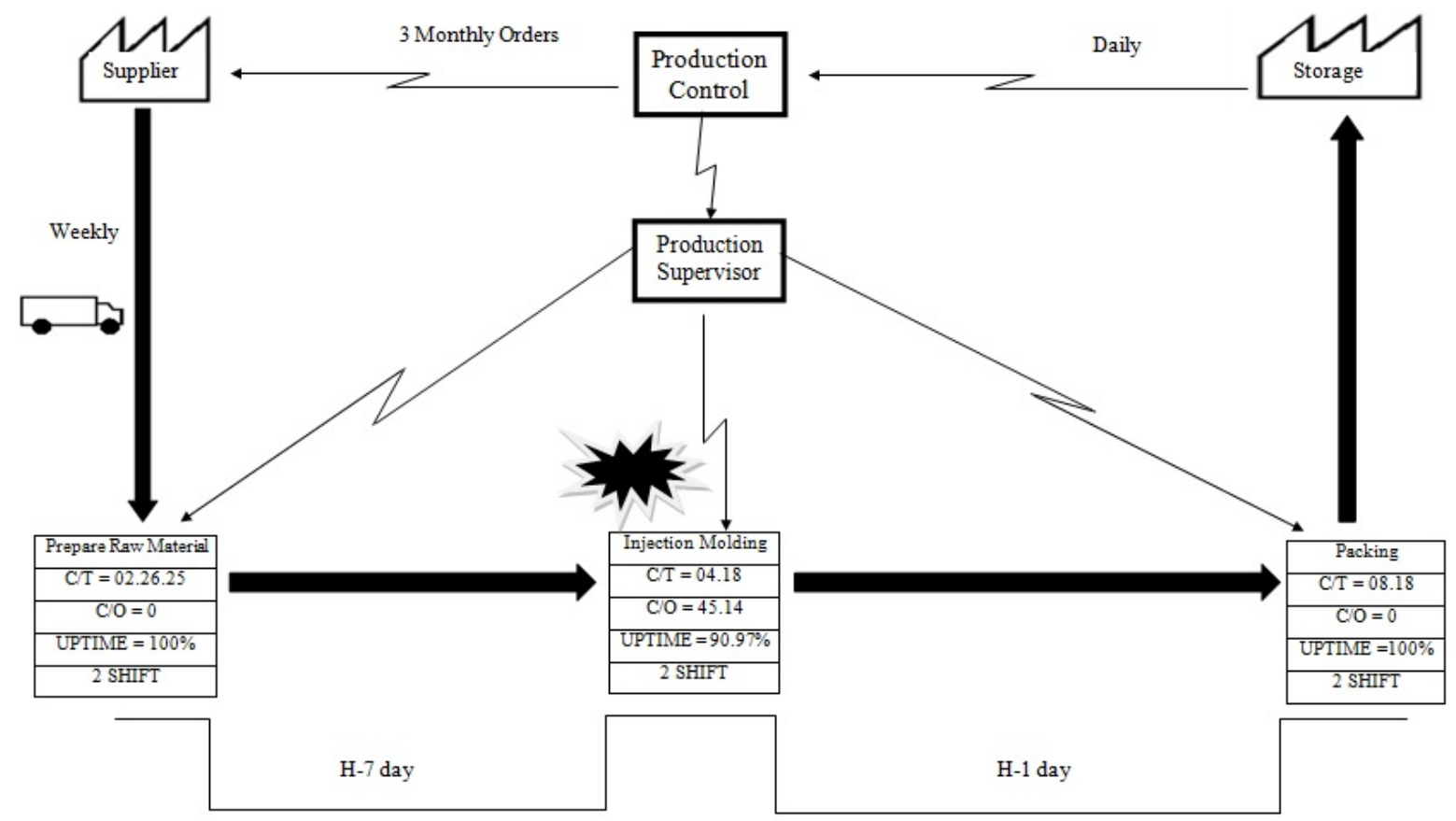

Figure 5. Future State Map 
It can be seen from the table above that the injection molding changeover time is reduced by 12.01 minutes with increased uptime of $2.4 \%$. with reduced changeover time affecting increased productivity.

Then fix the root of the problem that has been found and explained in the analyze stage using FMEA (Faillure Mode and Effect Analysis). FMEA analysis was carried out with the FMEA spree sheet. Every problem of the problem is sought for the value of the RPN then the value of the

RPN is arranged from the largest value to the smallest value. The cause that has the greatest RPN value is the main cause of the problems faced. The value of RPN is the product of the multiplication of the severity, occurence, and detection of each cause of the problem.

Table 9. FMEA defect silver streak

\begin{tabular}{|c|c|c|c|c|c|c|c|c|}
\hline $\begin{array}{l}\text { Type of } \\
\text { Defects }\end{array}$ & Severity & $\begin{array}{l}\text { Cause of } \\
\text { Defects }\end{array}$ & Occurance & Current Control & Detection & $\begin{array}{l}\text { Recommended } \\
\text { Action }\end{array}$ & RPN & Rank \\
\hline \multirow{4}{*}{$\begin{array}{l}\text { Silver } \\
\text { Streak }\end{array}$} & 10 & $\begin{array}{c}\text { Material } \\
\text { mixed } \\
\text { between PP \& } \\
\text { ABS }\end{array}$ & 8 & $\begin{array}{l}\text { When the production } \\
\text { process with ABS material } \\
\text { and continued with PP } \\
\text { material, or vice versa. } \\
\text { When the material changes } \\
\text { there are still remaining } \\
\text { material in the injection } \\
\text { machine barrel. }\end{array}$ & 3 & $\begin{array}{c}\text { Separation of } \\
\text { machines between } \\
\text { production uses PP } \\
\text { material and ABS } \\
\text { material. } \\
\text { Washing the barrel } \\
\text { so that the remaining } \\
\text { material is clean } \\
\text { inside the barrel. }\end{array}$ & 240 & 1 \\
\hline & 2 & $\begin{array}{c}\text { Too many } \\
\text { Recycle mixes }\end{array}$ & 6 & $\begin{array}{l}\text { Trial mixing material is } \\
\text { recycled by the quality team } \\
\text { and maker }\end{array}$ & 3 & $\begin{array}{l}\text { Mixing must not } \\
\text { exceed the } 10 \% \text { limit }\end{array}$ & 36 & 4 \\
\hline & 10 & $\begin{array}{l}\text { Material is } \\
\text { still cold / still } \\
\text { has a lot of } \\
\text { water content }\end{array}$ & 7 & $\begin{array}{l}\text { Check the hopper dryer } \\
\text { temperature and material } \\
\text { drying time for the material }\end{array}$ & 2 & $\begin{array}{l}\text { Setting parameters of } \\
\text { hopper dryer } \\
\text { temperature and } \\
\text { drying time } \\
\text { according to standard }\end{array}$ & 140 & 3 \\
\hline & 9 & $\begin{array}{l}\text { Machine } \\
\text { setting } \\
\text { parameters }\end{array}$ & 7 & $\begin{array}{l}\text { Check production } \\
\text { according to the sample } \\
\text { limit }\end{array}$ & 3 & $\begin{array}{l}\text { Parameter settings } \\
\text { according to standard }\end{array}$ & 189 & 2 \\
\hline
\end{tabular}

Source: PT. Suzuki Indomobil Motor

Example of FMEA score calculation table as follows:

In the cause of defect: material mixed between PP \& ABS

$\mathrm{RPN}=$ severity $\mathrm{x}$ assurance $\mathrm{x}$ detection

$$
\begin{aligned}
& =10 \times 8 \times 3 \\
& =240
\end{aligned}
$$

\subsection{Control Phase}

The control or control stage is the last step in the DMAIC method. The main target at the control stage is controlling the process so that problems that arise in the old process do not recur. The control phase that is carried out is only a proposal to be implemented by the company. Control activities that can be carried out are monitored by using a control sheet which aims to control whether the material baking process in the hopper dryer is in accordance with the standard or not. The following is an example of a control sheet found in the table. 
Table 10. Control sheet

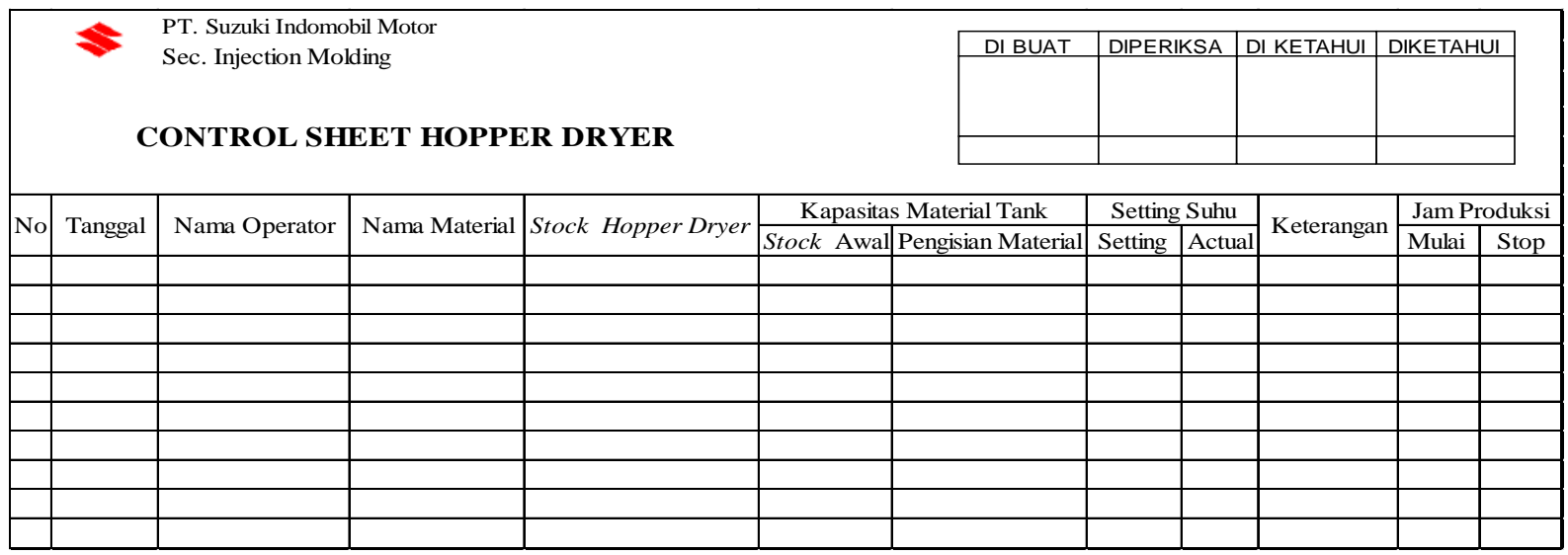

\section{Analysis}

Table 11. Results and Analysis

\begin{tabular}{|c|c|c|}
\hline DMAIC & Tools & Value \\
\hline \multirow{4}{*}{ Define } & SIPOC Diagram & Filled with suppliers, inputs, processes, outputs, customers for part garnish back door license \\
\hline & Operation Process Chart & Contains the operation process of the garnish back door license part \\
\hline & CTQ (Critical to Quality) & No silver streak, no shock, no weld line, no short shoot, no flowmark, others \\
\hline & Current State Map & Non-value added in the injection molding process 57.15 minutes with uptime of $88.57 \%$ \\
\hline \multirow{5}{*}{ Measure } & Pareto diagram & Defect silver streak as big as $43 \%$ \\
\hline & Control Chart & Out of control on 25 \& 28 January 2019 \\
\hline & DPO \& DPMO & $\begin{array}{c}\mathrm{DPO}=0.0152 \\
\mathrm{DPMO}=15152\end{array}$ \\
\hline & SQL (Sigma Quality Level) & 3.4 sigma \\
\hline & Yield Process & $92 \%$ \\
\hline Analyze & Fishbone Diagram & Defect silver streak is caused by human, machine, method, environment, material \\
\hline \multirow[b]{2}{*}{ Improve } & Future State Map & Increased uptime by $2.4 \%$ with a reduction in time of 12.01 minutes \\
\hline & $\begin{array}{l}\text { FMEA (Faillure Mode and } \\
\text { Effect Analysis) }\end{array}$ & $\begin{array}{l}\text { The highest RPN score is } 240 \text { and is ranked } 1 \text { (one), which is the mixing of material between } \\
\text { PP and ABS. }\end{array}$ \\
\hline Control & Control Sheet & $\begin{array}{l}\text { Making control sheet for section material so that the material capacity and temperature in the } \\
\text { hopper dryer can be seen in its development. }\end{array}$ \\
\hline
\end{tabular}

\section{Conclusions}

1. In the value stream mapping process, a current state map that contains a map of the process of injection molding can be made starting from the preparation of raw materials, the injection molding process, and the packing process, in the current state map there is a non-value added injection change molding machine. Therefore, improvements to the future state map are made to improve the process by heating the dies before dies up to the injection machine, and these improvements can reduce heater mold heating time by $2.4 \%$ or 12.01 minutes with reduced changeover time affecting increased productivity.

2. By using the DMAIC method (define, measure, analyze, improve, control), it is expected to improve, and increase the sigma level while maintaining the quality of the products produced by PT. Suzuki Indomobil Motor. Improvements that can be done by PT. Suzuki Indomobil Motor to minimize silver streak defects are to use 1 machine in 1 type of material, so there is no barrel washing process due to the process of washing the material from ABS material to PP material, then controlling the hopper dryer so that the temperature in the hopper dryer remains in standard temperature determined by PT. Suzuki Indomobil Motor.

3. Based on The Journal of quality improvement in plastic injection molding industry, the Authors started off by selecting the product with the highest rejection percentage which turned out to be Floor Trap 6x4x2. They then classified the types of defects and defects produced in this type of product. The current performance of the injection molding process was 
evaluated in terms of sigma level and DPMO. This acted as a baseline for our study. In order to find the root causes of the problem, a Fishbone diagram was constructed. Brainstorming sessions were useful in selecting the most appropriate causes that had an influence on the number of defects produced.

Following that, DOE was used to find the optimum parameters of the injection speed, injection pressure, and melting temperature that would produce the minimum number of defects. Other causes such as the operator's behavior, mold surface and so on, were considered in the FMEA. Actions that would reduce the number of defects were implemented, and recommended to Company XYZ.

After improving the system, the sigma level has increased from $1.4 \sigma$ to $2.3 \sigma$ and DPMO has decreased from 516,500 to 190,000 . This improvement accounts for more than $50 \%$ of process improvement. A control chart was used to check for stability of the process, and an Out-of-Control-Action plan was provided to the company for maintaining the process improvements. The improvement that we have made will increase profits made by the organization and improve the overall performance of the injection molding process.

\section{REFERENCE}

[1] Alshammari, A., Redha, S., et al. 2018. Quality Improvement in Plastic Injection Molding Industry: Applying Lean Six Sigma to SME in Kuwait. Proceedings of the International Conference on Industrial Engineering and Operations Management.

[2] Gaspersz, V. 1998. Statistical Process Control: Total Business Management. Jakarta: Gramedia Pustaka Utama

[3] Hassan, M. K. 2013. Applying Lean Six Sigma For Waste Reduction In A Manufacturing Environment. American Journal Of Industrial Engineering. Vol 1 (2), 28-35.

[4] Jeong, B. K., Yoon, T. E. 2016. Improving It Process Management Through Value Stream Mapping Approach: A Case Study. Journal of Information Systems and Technology Management, Vol 13, No. 03, pp. 389-404

[5] Pande, P. S., Robert, P., et al. 2002. The Six Sigma Way. Yogyakarta: Andi.

[6] Purnomo, H. 2003. Introduction to Industrial Engineering. Graha Ilmu:Yoygakarta.

[7] Salomon, L. L., Ahmad, et al. 2015. Strategy for Improving the Quality of Clear Parts Using the Six Sigma Method Approach. Journal of Industrial Engineering Scientific, Vol. 3, No. 3, pp. 156-165

[8] Sugiyono 2012 Business Research Methods. Bandung: Alfabeta.

[9] Sumayang. 2003. Fundamentals of Production and Operations Management. Jakarta: Salemba Empat Publisher.
[10] Syukron, A. dan Kholil, M., 2013. Six Sigma (Quality For Business Improvement). Yogyakarta: Graha Ilmu

[11] Yadav, J. S., Kaushik, P. 2014. Application Of Six Sigma In Injection Molding Process. International Journal Of R\&D In Engineering, Science And Management. Vol 1, pp:8-16. 